\title{
Rex Iuba, monarca e intelectual helenístico, y la Hispania de Augusto
}

\author{
Adolfo J. Domínguez Monedero \\ Universidad Autónoma de Madrid \\ adolfo.dominguez@uam.es
}

\begin{abstract}
RESUMEN
El rey Juba II, situado por Augusto al frente del reino cliente de Mauretania aparece muy relacionado con la Hispania romana, muy en especial con las ciudades de Gades y Carthago Nova. Además de las razones que se han aducido para esa relación, el presente artículo explora otras posibilidades que tienen en buena parte que ver con la actividad del rey como investigador y como erudito y con el desarrollo de una importante ideología política que, siempre dentro del marco jurídico romano, pretende resaltar las múltiples herencias que concentra el rey en su persona y en su familia (púnica, númida, helenística). Las dos ciudades de Hispania en las que el rey es honrado y donde ejerce su evergetismo deben ser estudiadas en conjunción con los otros ámbitos externos a su reino donde se atestiguan sus intereses, tanto los territorios atlánticos como uno de los centros culturales del mundo antiguo, Atenas.
\end{abstract}

Palabras clave: Juba II. Mauretania. Gades. Carthago Nova. Geografía. Exploraciones.

\section{Rex Iuba, a Hellenistic King and Intellectual, and the Hispania of Augustus}

\begin{abstract}
King Juba II, placed in the throne of the client-kingdom of Mauretania by Augustus, appears closely related to the Roman Hispania, especially to the cities of Gades and Carthago Nova. In addition to the reasons adduced by the scholarship for this relationship, this article explores other possibilities which have largely to do with the activity of the king as a researcher and scholar and the development of a major political ideology, always within the legal Roman framework, aimed to highlight the many legacies that the king concentrates in his person and in his family (Punic, Numidian, Hellenistic). The two cities of Hispania in which the king is honoured and where he exerts his evergetism should be studied in conjunction with other places outside his kingdom where his interests are also attested, namely the Atlantic territories and one of the cultural centres of the ancient world, Athens.
\end{abstract}

Key Words: Juba II. Mauretania. Gades. Carthago Nova. Geography. Explorations. 
El rey Juba de II de Mauretania ha sido una figura que no ha pasado inadvertida a la investigación, tanto nacional como extranjera, debido a varios factores. Entre ellos destacaría sobre todo, además de su faceta política como gobernante, su profunda formación intelectual, que le convirtió en un prolífico autor de obras sobre diversos temas propios de la erudición tardo-helenística. ${ }^{1}$ Sin que ello haga de él un personaje único, sí que es un aspecto que no deja de llamar la atención puesto que la propia actividad política desarrollada por el rey, que no fue tampoco menor en el conflictivo y bastante artificial reino que Augusto le otorgó, debió de ocupar también una parte importante de sus energías.

En la formación de Juba inciden, sin duda, diversos factores que debieron de jugar su papel de manera distinta a lo largo de su vida. Por una parte, su herencia africana o, quizá con más propiedad, siquiera desde el punto de vista del historiador actual, púnico-africana. Juba es el penúltimo representante de una larga e influyente familia de dinastas del pueblo númida maesilio entre los que destacan figuras bien conocidas por las fuentes grecorromanas como Juba I, su padre, o Hiempsal II, su abuelo, o Yugurta o Masinisa. ${ }^{2}$ Su nombre, 'Iov́ßas en griego o Iuba en latín, parece derivar de una palabra neopúnica, $Y w b\left({ }^{\prime}\right),{ }^{3}$ lo que, al igual que el de su padre, resaltaba el estrecho vínculo cultural entre las élites númidas y una herencia púnica aún dominante en esos territorios incluso después de la caída de Cartago. ${ }^{4}$

En el momento en el que se produce la muerte de su padre y la caída de su reino (46 a.C.) Juba II era aún un niño (habría nacido entre el 52 y el 50 a.C.) por lo que su formación apenas se habría iniciado. Sería tras convertirse en protegido de César y luego de su hijo adoptivo, Octaviano, cuando el príncipe proseguiría su formación en un entorno en el que la lengua griega jugaría un papel predominante como correspondería, tal vez, a la imagen que los romanos se harían de un príncipe destronado y puesto bajo la tutela de Roma, pero que había nacido en una corte ya influida por la cultura griega. ${ }^{5} \mathrm{Su}$ abuelo Hiempsal II había mostrado un interés erudito por la cultura grecorromana ${ }^{6}$ y había compuesto o, según otros, traducido al griego unos Libri Punici (Sall., J. XVII 7) ${ }^{7}$ que, a partir del testimonio de Plinio (N.H. XVIII 22) serían los mismos que los romanos habían entregado, tras la destrucción de Cartago, a reguli Africae, seguramente los monarcas númidas. ${ }^{8}$ En estos Libri Punici, que también parece haber usado para sus obras el propio Juba (Amm. Marc. XXII 15.8), se encontrarían numerosas noticias sobre diversos temas, tanto geográficos como históricos y etnográficos y, merced al acto de cesión de los romanos recordado por Plinio,

1 Roller 2003, 163-182.

2 Ver stemma en Coltelloni-Trannoy 1997, 14.

3 GARCí́ 2007, 6; otros autores sugieren, sin embargo, que se trata de un nombre teóforo correspondiente a una divinidad libia: Coltelloni-Trannoy 1997, 199. Roller 2003, 1, sugiere que el nombre Juba le fue asignado por los romanos a partir del de su padre.

4 Sobre el importante influjo que Cartago había ejercido sobre todo ese mundo númida vid. GozALBES 2014, 277-279.

5 Desanges 1989, 53-61.

6 KonTORINi 1975, 89-99.

7 Desanges 1989, 53-54.

8 Matthews 1972, 330-335; vid. también Krings 1990, 109-117. 
los reyes númidas se habrían convertido en depositarios de ese legado. Esa herencia púnica ya la había exhibido su padre, el rey Juba I, que en sus monedas, además de su título en latín (REXIVBA) añade letreros en neopúnico que superan las escasas letras que sus antecesores habían colocado en sus propias acuñaciones. ${ }^{9}$

En el caso de Juba II esos rasgos de tradición púnica aparecerán en otros aspectos de sus monedas, en especial en algunos de los temas iconográficos elegidos (Hércules-Melqart), ${ }^{10} \mathrm{y}$ en los que quizá combine las tradiciones de este tipo propias de la zona de la que procedía, la Numidia, con las de ese mismo origen pero posiblemente distintas del reino que recibe, la Mauretania. ${ }^{11}$ Es probable que, tal vez por la educación recibida, o por una opción personal, Juba haya querido cultivar también una clara imagen de monarca helenístico, como se comprueba en los retratos suyos conocidos, ${ }^{12}$ (Fig. 1) algo que su matrimonio en el año sexto de su reinado (19 a.C.) con Cleopatra Selene, la hija de Cleopatra VII y Marco Antonio (Dio Cass., LI 15.6), no podía sino ayudar a reforzar. ${ }^{13}$

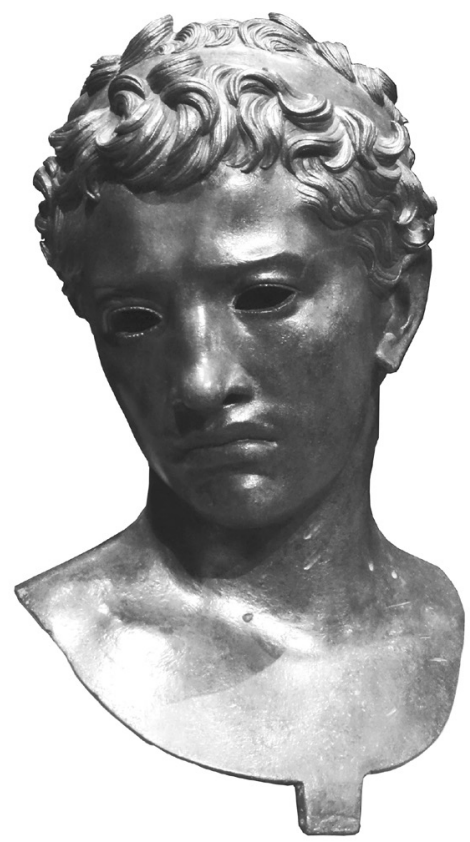

Fig. 1. Retrato en bronce de Juba II, hallado en Volubilis. (Fotografía del autor).

9 MÜller 1862, 46-47.

10 Alexandropoulos 2000, 228-230.

11 Alexandropoulos 2000, 228-229 ha subrayado el paso de una zona (Numidia) más vinculada a BaalHammón a otra (Mauretania) dominada por Melqart.

12 LANDWEHR 2007, 65-110.

13 Braund 1984a, 175-178. Tanto la entrega del reino de Mauretania a Juba como su matrimonio con Cleopatra Selene son facetas de la política imperialista romana: MATTINGLY 2011, 77-78. 
Dentro de las abundantes emisiones monetales correspondientes a su reinado, en las que de forma sistemática el rey aparece, igual que lo había hecho su padre, como REX IVBA, hay alguna acuñación, escasa y en bronce, en la que este título aparece en griego y en genitivo, BA $\Sigma \mathrm{I} \Lambda \mathrm{E} \Omega[\Sigma] \mathrm{I} \Omega \mathrm{BA}$. Esta moneda corresponde sin duda al inicio del reinado, porque es muy semejante a una acuñada durante el periodo del llamado "interregno" previo a su nombramiento como rey. ${ }^{14}$ En las monedas que se acuñan con el nombre del rey y de su esposa, el primero aparece invariablemente en latín y en nominativo (REX IVBA) mientras que el de la reina aparece siempre en griego $\mathrm{y}$, en apariencia, en nominativo (BA $\Sigma \mathrm{I} \Lambda \mathrm{I} \Sigma \Sigma \mathrm{A} \mathrm{K} \Lambda \mathrm{EO \Pi ATPA}),{ }^{15}$ haciendo clara referencia al título de su madre Cleopatra VII. ${ }^{16}$ (Fig. 2) Solo en una ocasión aparece el

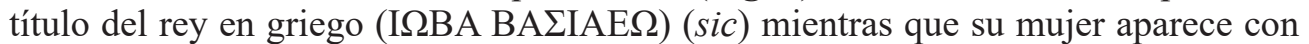
su "verdadero" nombre, $\Sigma$ E $\Lambda$ EN (Dio. Cass., L 21.3; cf. Plut., Ant. 36.5), lo que es bastante inusual. ${ }^{17}$ Aunque no sabemos el contexto exacto de estas acuñaciones con titulación en griego, tal vez las mismas correspondan al periodo del enlace entre estos dos personajes, lo que acaso le llevase al rey a adoptar el griego como denominación oficial de su cargo. No obstante, la escasez de estas acuñaciones sugiere que, por propia voluntad o por haber recibido presiones de distinto tipo ${ }^{18}$ pronto abandonó esta práctica para volver a la terminología latina, aun cuando para nombrar a la reina se mantuvo el griego.
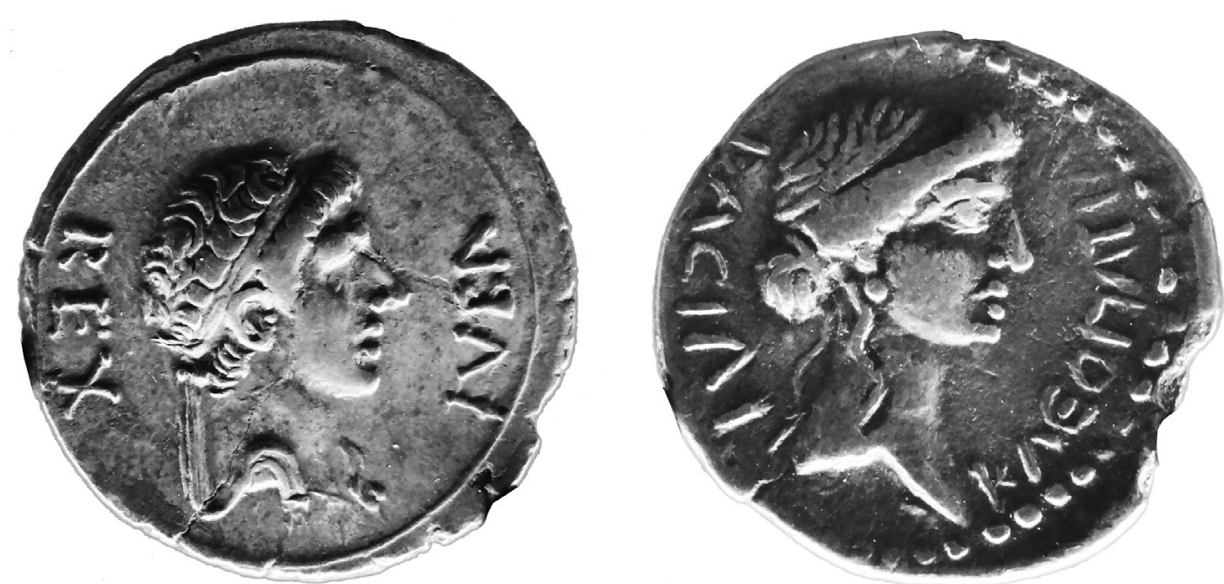

Fig. 2. Monedas con busto de Juba II y de Cleopatra Selene. (Fotografía del autor).

14 Müller 1862, 107, núm. 75; 117; MAZARD 1955, 101, núm. 270; la moneda del interregno, IBID. 70, núm. 124. Sobre este periodo vid. también AMELA 2012a, 38-41.

15 GRENIER 2001, 101-116.

16 Tyldesley 2008, 201.

17 Müller 1874, 74-75, núm. 102a; Mazard 1955, 116, núm. 345. Aunque este autor la considera del inicio del reinado, seguramente hay que llevarla, al menos, al periodo del matrimonio con Cleopatra Selene.

18 Sobre la posibilidad de presiones, García 2007, 14, nota 30. En cualquier caso, el uso del griego en la numismática africana es muy escaso: AleXANDropoulos 2002-2003, 289-296. Fuera de la moneda, su uso tampoco parece haber sido muy extendido: COLTELLONI-TrannOy 2005b, 69-117. 
De cualquier modo, estas escasas acuñaciones en griego apuntan también a que Juba II debió de tratar de presentar su realeza vinculada a la tradición helenística, como era habitual en la familia real númida, por más que la misma no fuese más que una concesión de su protector Augusto. Los antepasados de Juba habían mantenido buenas relaciones desde hacía tiempo con distintos ámbitos del mundo helenístico, incluyendo el Egipto ptolemaico ${ }^{19}$ y el que su hijo y sucesor recibiese el nombre real de Ptolomeo muestra, además de la influencia de la reina Cleopatra, que Juba aceptó de buen grado el doble papel de perpetuador de su propia dinastía pero también de la dinastía lágida.

Un acontecimiento fundamental en la relación de Juba con Hispania fue, sin ninguna duda, el traslado desde su Numidia natal hasta el nuevo reino que Augusto le otorgó en el extremo occidental africano (Str., VI 4.2; XVII, 3, 7; Tac., Ann., IV 4.3), la Mauretania, que era propiedad de Roma desde la muerte de Boco II, antes de la cual había experimentado importantes convulsiones. ${ }^{20}$ Con anterioridad, Juba habría acompañado a Augusto en su campaña hispánica contra cántabros y astures como sugiere algún autor antiguo (Dio Cass., LI 15.6) y tras su final se habría producido su nombramiento como rey de la Mauretania, a la que se le añadió algún otro territorio, ${ }^{21}$ engrosando así la lista de los "reyes clientes" romanos. ${ }^{22}$

Juba II estableció como su capital la ciudad de Iol, que ya habría actuado como tal con Boco II (Solin., 25.16), ${ }^{23}$ aunque renombrándola Cesarea (Str., XVII 3.12; Plin. N.H. V 20; Mela, I 30), la cual se encontraba en la parte oriental de su reino. No obstante, una parte importante del territorio bajo su control se encontraba más al oeste en la región en torno a Tingi (Tánger) cuyas relaciones con la Península Ibérica habían sido desde siempre muy intensas y que, además, controlaba la parte africana del Estrecho de Gibraltar. Es bastante posible que fuese esta proximidad entre su reino y la Hispania romana, y la comunidad de intereses entre el sur de esta y la parte más occidental de su reino lo que favoreció las relaciones del rey con algunas partes del territorio hispánico. ${ }^{24}$

Sin embargo, y antes de considerar las mismas, no podemos perder de vista que Juba II también mantuvo contactos y relaciones, que dejaron sus huellas, con otros territorios del Imperio. Además de la ya mencionada posible presencia en las campañas hispánicas de Augusto, quizá había acompañado a su protector en la expedición que acabaría con la flota de Antonio y Cleopatra en Accio ${ }^{25}$ y Pausanias nos informa de que había una estatua suya en Atenas (I 17.2) y no en un lugar cualquiera sino

19 Coltelloni-Trannoy 1992, 71-72.

20 Gozalbes 2010, 119-144; Amela 2012b, 149-167.

21 Coltelloni-Trannoy 1997, 38, 74-75; Coltelloni-trannoy 2011, 87-109.

22 Coltelloni-Trannoy 2005a, 117-144.

23 Coltelloni-Trannoy 1997, 80-81.

24 La revitalización de las relaciones entre estos territorios del llamado "Círculo del Estrecho" en el periodo de Juba II ha sido abordada por CALLEGARIN 2008, 312-315.

25 La referencia de Dión Casio LI 15.6 realmente es muy escueta y dice tan solo que Juba había sido

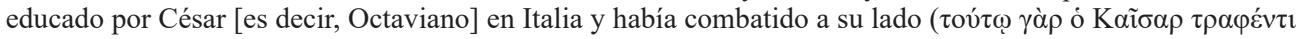

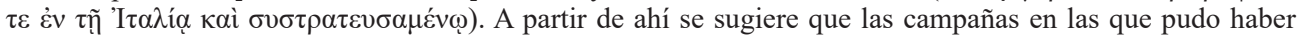
participado el príncipe antes de ser nombrado rey pudieron haber sido las de Accio y/o las Guerras Cántabras. Vid. al respecto Gsell 1928, 208. 
en el gimnasio que se encontraba cerca del ágora y que fundó uno de los Ptolomeos egipcios. ${ }^{26}$ Quizá esa estatua se deba a que el rey mauretano pagó la reconstrucción del edificio ${ }^{27} \mathrm{O}$ a que realizase alguna actividad benéfica en favor del mismo. ${ }^{28}$ Atenas jugaba un papel importante como "escaparate", al ser el principal centro cultural del Imperio Romano, y era por ello receptora de diversas ofrendas por parte de reyes clientes, los cuales solían recibir, como contrapartida, estatuas en la acrópolis; la única excepción a esta norma la constituyó Juba II, ${ }^{29}$ no porque no hubiera una estatua suya en la acrópolis, que sí la había $\left(I G \mathrm{II}^{2}, 3436\right)$, sino porque además tuvo la otra ya mencionada en el Gimnasio de Ptolomeo. Creo que pocas dudas pueden caber de que esta estatua y los beneficios que pudo aportar al gimnasio ptolemaico están íntimamente unidos a su matrimonio con Cleopatra Selene y al hecho de ser el padre del último heredero de la dinastía lágida. Por otro lado, es difícil saber si en el ánimo de los atenienses habría jugado un papel más relevante esta condición de Juba como esposo y padre de miembros de la dinastía lágida o la de ciudadano romano, pues es conocida la reticencia de Atenas, frente a otras ciudades griegas, a honrar a romanos. ${ }^{30}$

Además del propio rey, otros miembros de su familia fueron honrados por la ciudad de Atenas, como su segunda esposa Glafira, hija del rey Arquelao $\left(I G \mathrm{II}^{2}\right.$, $3437 / 8=O G I S 363)$, su hijo Ptolomeo (OGIS 197) y otra hija desconocida (IG $\mathrm{II}^{2}$, 3439) (¿Drusila?; Tac., Hist. V 9). ${ }^{31}$

Es probable que Juba estuviese en Atenas con motivo de la erección de sus estatuas en la acrópolis o en el gimnasio; del mismo modo, parece claro que el rey se trasladó hasta Oriente para participar en la expedición de Cayo César, entre el 1 y el 4 d.C., momento en el que se casaría con Glafira; ${ }^{32}$ en este viaje recabaría informaciones para su obra Sobre Arabia, que habría sido escrita para dotar al nieto e hijo adoptivo de Augusto de informaciones sobre los territorios en los que debía actuar (Plin., N.H. VI 141; XII 57; XXXII 10). ${ }^{33}$ Este matrimonio se disolvería pronto, quizá poco después de la muerte de Cayo César y no, como por error asegura Josefo, por el fallecimiento del rey (Jos., $B J$ II 114-115; $A J$ XVII 349-350). ${ }^{34}$ Como no parece que Glafira llegase a trasladarse a Mauretania (aunque sí a Atenas, como vimos), el matrimonio y el breve periodo de convivencia de Juba con su esposa debió de tener

26 Sobre cuál de los Ptolomeos pudo haber sido, vid. Roller 2003, 136-137, con la bibliografía previa, que piensa bien en Ptolomeo III o en el VI. Sobre la ubicación del gimnasio, CAMP 2001, 168, 170 y 178-179, que sugiere que también los Ptolomeos construirían el reloj conocido como la "Torre de los Vientos", que estaría cerca del gimnasio.

27 Miller 1995, 208.

28 BRAUND 1984b, 78.

29 BRAUND 1984b, 78-79.

30 PARIGI 2013, 448-449.

31 Schmalz 2009, 126, núm. 157; KokKinos 1987, 288-290. Sobre las relaciones entre esos "reyes clientes" vid. JACOBSON 2001, 22-38; sobre la extensión de esta figura a África, Coltelloni-TranNOY 2005a, 117-144.

32 GARCía 2007, 64-65; ROLLER 2003, 212-226.

33 Coltelloni-Trannoy 1997, 140-141; Luther 2010, 103-127.

34 Este error de Josefo es notorio ya desde los trabajos más antiguos dedicados al rey; vid., por ejemplo, BLANCHÈRE 1883, 98-99, quien señala también que Glafira no fue nunca a Mauretania. 
lugar en Oriente, donde el monarca debió de compatibilizar sus funciones políticas y, eventualmente, representativas con sus labores de investigación. ${ }^{35}$

El establecimiento de su capital en la antigua ciudad fenicia de Iol vincula el reino de Juba con el de sus predecesores; los autores antiguos insisten en que se trataba de una ciudad antes poco conocida (aliquando ignobilis: Mela, I 30) que, sin embargo,

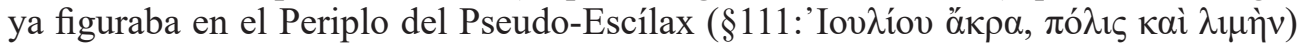
situada en el trayecto marítimo que desde Cartago llevaba hasta la Columna de Heracles africana. ${ }^{36}$ Por desgracia, apenas tenemos datos de ese centro fenicio, pero no cabe duda de que debió de estar en contacto tanto con el área de Cartago como con el ámbito fenicio de la Península Ibérica, en especial con Gadir, a donde conducía el trayecto marítimo que recoge la mencionada obra del Pseudo-Escílax.

Un aspecto interesante de la labor propagandística de Juba II, quizá en su afán de parangonarse a la prestigiosa línea dinástica de su esposa, fue considerarse descendiente nada menos que de Heracles. En un pasaje de la biografía de Sertorio de Plutarco, asegura el autor que en Tingis se hallaba la tumba de Anteo, cuya viuda, Tinga, se habría unido a Heracles y de esa unión habría nacido Sophax que habría reinado sobre el país y fundado la ciudad de Tingis en honor a su madre. Tras relatar la historia, Plutarco afirma, sin embargo, que "todas estas cosas se le ofrecieron a la gloria de Juba, el más dedicado a la historia de todos los reyes; se cuenta, en efecto que aquél era descendiente de Sophax y de Diodoro" (Plut., Sert. IX). ${ }^{37}$ En esta visión hay una buena parte de propaganda, quizá en función de sus nuevos súbditos y, como observaba Plutarco, una parte importante de erudición; el rey habría promovido, o permitido y auspiciado, la propagación de esa leyenda que le dotaba de unos antepasados míticos ilustres tan arraigados en ese mundo norteafricano, donde la figura de Heracles, es decir, de Melqart, tenía tanto peso; ${ }^{38}$ además de ello, el uso de Heracles como divinidad legitimadora tiene una amplísima tradición en el mundo griego. ${ }^{39} \mathrm{En}$ las monedas de tema heracleo acuñadas por este rey se ha visto una síntesis entre las representaciones de soberanos helenísticos como Heracles y el tipo iconográfico del Heracles-Hércules en el mundo helenístico romano, pero sin descartar tampoco un elemento africano ya presente en las monedas desde el s. III a.C.; el rey aparece en ocasiones tocado con la leontea y acompañado de la maza, en diversas combinaciones. ${ }^{40}$

Dentro del territorio de su reino había lugares vinculados al culto de Heracles, tanto la propia Tingis como sobre todo Lixus, donde Plinio sitúa el palacio de Anteo y el lugar de combate con Heracles así como el Jardín de las Hespérides (N.H. V 3) y su

35 Sobre los posibles resultados de esa labor, vid. BALLESTERos 2009, 217-231.

36 Sobre este tramo, con una toponimia en muchas ocasiones única, vid. PERETTi 1979, 354-364.

37 Sobre la posibilidad de que estas noticias procedan, en último término, de la actividad historiográfica del propio Juba, vid. Ballesteros 2013, 39, que considera también a Juba fuente la noticia de Justino (XLIV 4) sobre Gárgoris y Habis.

38 Vid. unas observaciones generales en García 2007, 99-109; vid. también Coltelloni-TranNOY 2002, 41-57; АMiтAY 2014, 1-28.

39 HutTNer 1997, passim y 211-220.

40 Salzmann 1974 175-176; Smadja 1994, 373-377; Mazard 1955, 79-80, 84-85, núms. 145, 148-152, 169-175. 
capital Cesarea también se convirtió en un lugar muy vinculado al culto heracleo; ${ }^{41}$ junto a ello, no cabe duda de que el principal lugar de culto de Heracles en todo el Occidente era Gades.

De no ser por una noticia que introduce Rufo Festo Avieno en su Ora Maritima, totalmente extemporánea dentro de la narración que está llevando a cabo, y basada en fuentes anteriores, alguna de ellas de gran antigüedad, no tendríamos conocimiento de la relación que mantuvo el rey Juba II con la ciudad de Gades. Asegura el poeta romano, para contrastar la pobreza e insignificancia de la Gades contemporánea a su época (s. IV d.C.) (egena, brevis, destituta) que "tan grande fue su poder o más bien su gloria en tiempos muy antiguos, que, según la tradición, un soberbio rey - y quizá el más poderoso de cuantos por entonces tenía la nación maurusia, apreciadísimo por el príncipe Octaviano, dedicado continuamente al estudio de las letras, Juba, y separado por el mar intermedio - se creía muy honrado en ser el duunviro de esa ciudad" $(O M, 275-283$; trad. de P. Villalba). La información es valiosa porque del texto del propio Avieno se desprende que él mismo había estado en Gades (OM, 273-274). ${ }^{42}$ Por ende, el que un cargo semejante lo haya desempeñado también Juba en la ciudad de Carthago Nova, como veremos más adelante, sirve de elemento adicional de confirmación de esta noticia.

No disponemos de demasiados datos sobre la relación que pudo tener Juba II con Gades, pero la misma pudo verse favorecida por la genealogía heraclea que el rey empezó a desarrollar en un momento de su reinado y que tenía una clara relación con el dominio que los romanos le habían asignado sobre esa parte de la Mauretania tan vinculada desde siempre a la región gadirita como muestran, entre otros testimonios, los datos de la circulación de sus monedas en aquel territorio. ${ }^{43}$ Por otro lado, es posible que la ciudad necesitase ayuda o asistencia si tenemos en cuenta que algunos años antes del inicio de su reinado la misma había sufrido un duro asedio por parte de otro soberano mauretano, el rey Bogud. En efecto, una noticia de Porfirio (De abstin. I 25) indica que el rey Bogud, el que fue ejecutado por Agripa en Metone, había atacado el templo de Heracles durante el asedio al que sometió a la ciudad hacia el año 38 a.C. ${ }^{44}$ No cabe duda de que el rey Juba no habría perdido la oportunidad de realizar en una ciudad tan prestigiosa como Gades alguna acción de tipo benéfico que, además, le supusiese réditos políticos y propagandísticos. ${ }^{45}$ Es lo que, como veíamos antes, habría hecho en Atenas en favor del Gimnasio de Ptolomeo, que le habría abierto a él y, como sabemos, a su hijo la puerta a los honores en esa ciudad. Proponemos, pues, a título de hipótesis, que el rey Juba habría mostrado una especial atención a la ciudad de Gades y a su santuario principal vinculada a la vecindad e interdependencia

\footnotetext{
41 Smadja 1994, 379-380.

42 Sobre la existencia de una inscripción de cuyos datos podría haber tomado su información Avieno vid. PÉREZ 2003, 11-12; no todas sus observaciones, empero, son aceptables.

43 Alexandropoulos 2000, 228-229; Gozalbes 2007b, 39-55.

44 Amela 2012b, 353; Gozalbes 2003, 273-282. Sobre los prodigios que tuvieron lugar en el templo de Melqart durante el asedio vid. Álvarez 2014, 25-26.

$45 \mathrm{Y}$ es posible incluso, según una interpretación, que en una de las últimas monedas de su reinado pudiese aludir a que la muerte de este Bogud marcaba un nuevo comienzo para Mauretania junto con la victoria de Octavio en Accio; vid. Coltelloni-Trannoy 1990, 48.
} 
de ambos territorios, la Mauretania y la Bética, a los orígenes heracleos que el propio rey auspicia a través de las manipulaciones del mito y de las monedas y, tal vez, al deseo de compensar a la ciudad y a sus habitantes por las pérdidas y penurias que un antecesor suyo en el trono de Mauretania, Bogud, había causado durante su asedio. No deja de ser interesante observar que el ataque de Bogud a Gades se produjo al servicio de los intereses de Marco Antonio y ahora era un rey, casado con la hija del antiguo triunviro, quien auxiliaba a la ciudad.

No cabe duda, en todo caso, de que Juba estableció unos vínculos sólidos con Gades, saldados con la concesión del duunvirato por parte de la ciudad; aun cuando no sabemos si el desempeño de esta magistratura llevó implícito, como en el caso de Carthago Nova, la condición de patronus, bien atestiguada en esta última gracias a la epigrafía, ello no es improbable puesto que eso favorecería una relación más intensa entre el rey y la ciudad. ${ }^{46}$ Además de esos motivos, se nos ocurre otro más por el que Juba podría estar interesado en Gades y el mismo pudo deberse a su actividad científica, literaria e, incluso, exploratoria.

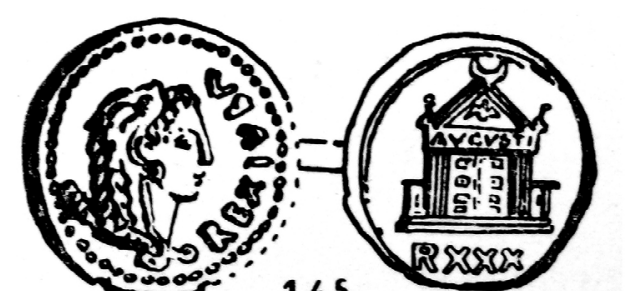

145

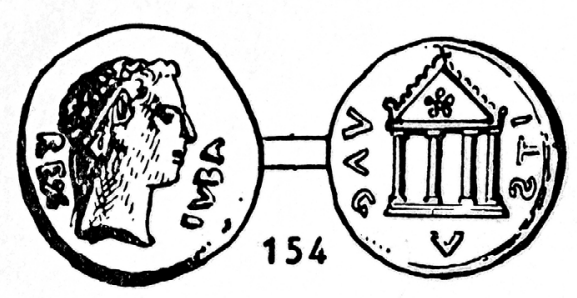

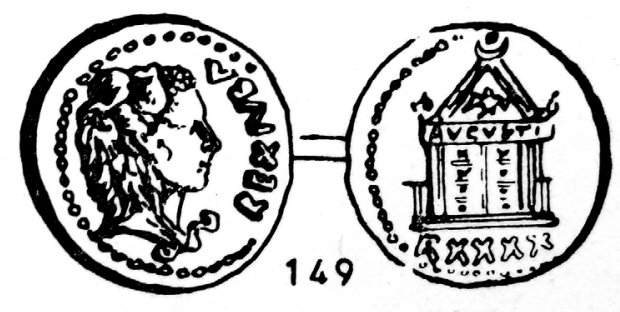

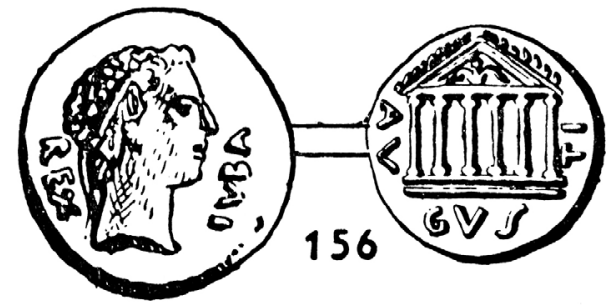

Fig. 3. Monedas de Juba II representado con leontea y templo oriental (núms. 145 y 149) y con busto diademado y templos de tipo clásico (núms. 154 y 156). (Según Mazard 1955).

En varios pasajes, los autores que citan las obras de Juba aluden a que el mismo está tomando algunos de sus datos de Libri Punici ${ }^{47}$, que pueden haber sido tanto esos libros que su abuelo Hiempsal II había usado, escrito o traducido como cualesquiera otros escritos originariamente en lengua púnica. Además de los restos dispersos de las bibliotecas de Cartago, a los que también nos hemos referido, había otros centros que, al menos de forma potencial, podían contar con otros tantos Libri Punici y uno de ellos sería Gades. Parece fuera de duda que, dentro de esa ciudad, el san-

46 Mangas 1988, 736.

47 Por ejemplo, Solino, XXXII 2; Amm. Marc., XXII 15.8. Sobre este asunto, vid. KrINGS 1991, 649-668. 
tuario de Melqart era un auténtico centro de sabiduría y se ha sugerido, con buenos argumentos, que en el mismo se conservarían noticias de muy diverso tipo y en especial las relacionadas con la exploración del Atlántico. ${ }^{48} \mathrm{Creo}$ posible que en algunas de las monedas de Juba pudiera estar representado el templo de Melqart en Gades, en especial en una que le muestra en el anverso tocado con la leontea del dios y con la maza. En el reverso aparece un templo coronado por un creciente y con las puertas cerradas; se trata de un templo que parece presentar dos grandes pilares o columnas, uno a cada lado de la puerta, bien visibles en los ejemplares mejor conservados. En el arquitrabe se puede leer $A V G V S T I$. Este tipo de moneda parece haber empezado a acuñarse en el año trigésimo de su reinado. ${ }^{49}$ (Fig. 3) En otras acuñaciones aparece también este tipo de templo, ${ }^{50}$ el cual contrasta, sin embargo, con otros templos de tipo más clásico tetrástilos ${ }^{51} \mathrm{y}$ hexástilos ${ }^{52}$ que figuran asimismo en sus monedas, aunque en estas la efigie del rey no aparece representada con los atributos de Heracles. (Fig. 4) Si estas monedas corresponden al periodo en el que el rey fue nombrado duunviro de Gades es algo que, aunque no podamos confirmarlo, tampoco podríamos descartarlo. Además de ello, resultaría bastante razonable ${ }^{53} \mathrm{e}$, incluso, podríamos datar ese hecho en torno al año 4 o 5 d.C. El letrero que alude a Augusto en el arquitrabe no es de extrañar, y más en monedas de Juba, puesto que la ciudad recibió el nombre de Municipium Augustum Gaditanum como muestra la epigrafía, ${ }^{54}$ y Plinio la llama Augustana Urbs Iulia Gaditana (Plin., N.H. IV 119). ${ }^{55}$ De cualquier modo, no podemos perder de vista que hay una corriente de pensamiento que pretende ver en todas estas imágenes de templos presentes en monedas occidentales de época de Augusto simples representaciones simbólicas sin alusión directa a ningún edificio real, opinión que no todo el mundo comparte. ${ }^{56}$

48 MARÍN - JiMÉNEZ 2011, 77-109.

49 Mazard 1955, núms. 144, 145.

50 MAZARD 1955, núms. 146, 147, 149. En opinión de SAlzmanN 1974, 175 este tipo se inspira en la curia representada en monedas augusteas posteriores a la victoria de Accio. Aunque es cierto que hay semejanzas entre la serie augustea y la de Juba, la del rey presenta elementos específicos como el creciente lunar que corona el edificio que no aparecen en la moneda del princeps; por su parte, MAZARD 1955, 80 sugiere que el tipo puede representar un templo dedicado a divinidades púnicas, pero consagrado también a Augusto; cf. GsELL 1928, 224. Ejemplos de edificios religiosos en monedas púnicas se observan también en monedas de Lixus del s. I a.C., lo que sugiere que no es algo extraño en las monedas mauretanas: MANFREDi 1996, 47-56. Del mismo modo, sobre la presencia de edificios de culto en monedas del ámbito púnico, incluyendo monedas de Juba I, vid. OgGiano 2008, 296-297.

51 MaZARD 1955, núms. 153, 154.

52 MAZARD 1955, núm. 156.

53 Sobre la presencia o no del templo de Melqart en las monedas romanas de Gades, vid., respectivamente, la discusión de GARCía y Bellido 1963, 102 y Mierse 1993, 38-40.

54 Por ejemplo, CIL II, 1313.

55 García Y Bellido 1963, 137 donde además plantea una asimilación entre Augusto y el Hércules gaditano.

56 En esta línea de interpretación simbólica se encuentra MiERSE 1993, 37-57 que, no obstante, reconoce la importante impronta púnica que subyace a la idea de representar edificios de culto. Queda por explicar, sin embargo, por qué se escogen tipos tan variados si, en último término, su significado es simbólico y, en otro trabajo, el mismo autor emplea la iconografía monetal como indicio del aspecto del templo de Afrodita en Pafos: Mierse 2004, 570. 

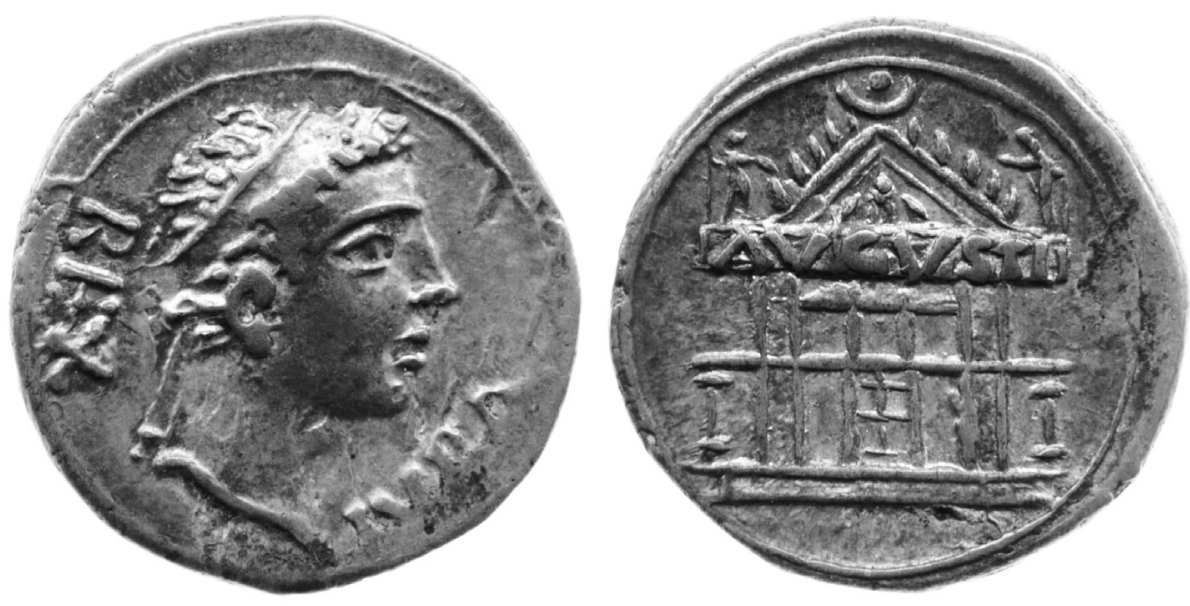

Fig. 4. Moneda de Juba II diademado y con templo de tipo oriental. (C) Trustees of the British Museum).

Como sabemos, entre las múltiples regiones en las que el rey Juba mostró interés desde el punto de vista de la geografía estaban los territorios africanos que se asoma-

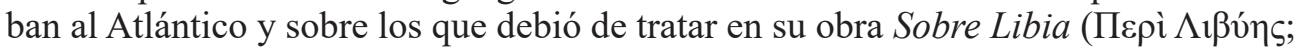
Athen., III 83B). ${ }^{57}$ Además, esos intereses tenían también implicaciones prácticas como se demuestra en el establecimiento de factorías dedicadas a la elaboración de la púrpura en unas islas que fueron llamadas Purpurariae Insulae que habría descubierto el propio rey (Plin., N.H. VI 201) y que se tienden a situar en Mogador ${ }^{58}$ aunque sin descartar otras posibilidades. ${ }^{59}$ Además de eso, Juba II pasa por haber sido el primero (o uno de los primeros) en haber mandado explorar las islas Canarias y haberlas descrito, ${ }^{60}$ aunque de su expedición apenas quedan más testimonios que los que recogen algunos autores posteriores en sus obras (Plin., N.H. VI 202-205; Solin., 56.14-19). ${ }^{61}$

En estas empresas atlánticas y en las obras geográficas derivadas de las mismas puede haber empleado como fuente principal, tal y como sugieren diversos autores, ${ }^{62}$

57 Sirago 1996, 303-317; Gozalbes 2011, 153-181. Para muchos críticos ésta habría sido su obra más destacada a partir, sobre todo, de sus posibles fuentes, tanto el relato de Hanón como los Libri Punici; vid. BLANCHÈre 1883, 116-117.

58 Sobre Mogador, Jodin 1967; López - Mederos 2008; Marzoli - El Khayari 2010, 61-108.

59 Entre ellas, las Islas Canarias; Álvarez 1946, 100-127; TARRADELL 1960, 260-261. Un panorama general, incluyendo las identificaciones propuestas en SANTANA et alii 2002, 184-190; BlÁzQUEz 2004, 697-699; Gozalbes 2007, 273-296. Sobre la elaboración de la púrpura en el litoral atlántico norteafricano, vid. MEDEROS - ESCRIBANO 2006, 71-96; BERNAL et alii 2014, 175-188.

60 La bibliografía sobre la exploración de las Canarias por Juba es muy abundante. De entre ella, destacamos los siguientes títulos: Álvarez 1945, 26-61; SCHMitt 1968, 362-391; BlázQuez 1977, 35-51; MedERos - ESCRIBANO 2002, 315-358; SANTANA et alii 2002, 225-320.

61 GARCía 2007, 220-270 y GARCía 2009, 141-164, con el estado de la cuestión y bibliografía previa. En último término, Mederos 2013, 239-268.

62 Gozalbes 2011, 160-162. 
el periplo de Hanón, en el que había tantas informaciones de interés derivadas de informaciones directas, ${ }^{63}$ pero es probable que no se haya limitado al mismo y haya tenido necesidad de disponer de más informaciones. Sin duda, su afición por hacerse con todo tipo de libros antiguos (Elias, In Cat. 28 a 23) le debió de llevar a conocer distintas tradiciones sobre islas en medio del Océano, de las cuales a nosotros no nos han quedado más que escasas referencias anteriores o contemporáneas al periodo de Juba. ${ }^{64}$ No sería improbable que todas esas referencias literarias le llevaran al rey a explorar las aguas atlánticas en busca de las mismas; en esta búsqueda Gades debía de jugar un papel importante porque hasta ella llegaban con frecuencia noticias de avistamientos de islas como muestra, por ejemplo, un conocido pasaje de la biografía plutarquea de Sertorio (Plut., Sert. 8) y otros casos sobre los que volveremos más adelante.

Como uno de los inspiradores de Juba se ha querido ver, sobre todo en los últimos tiempos, la figura de Estacio Seboso, un autor del que se conoce poco y cuya cronología sigue estando en disputa. No queda claro si es anterior o posterior a Juba II, lo que tiene su importancia porque según qué fecha se le asigne sus informaciones se habrían basado en las del rey o viceversa. ${ }^{65}$

Puesto que las fechas de Estacio Seboso siguen sin estar del todo claras, desde nuestro punto de vista, una fuente que puede haber empleado es el relato de Eudoxo de Cícico que llevó a cabo numerosas exploraciones a pesar de las dudas que expresa Estrabón, por más que para Posidonio haya tenido credibilidad (Str., II 3.5). Es, no obstante, el geógrafo de Amasia el que, basándose en el erudito de Apamea, nos da los principales datos sobre las expediciones de este aventurero. No retomaré aquí el conjunto de sus navegaciones, objeto de atención por parte de bastantes autores en los últimos tiempos, pero sí subrayaré algunos datos de su trayectoria que bien pudieran haber interesado al rey Juba. En primer lugar, su relación con el Egipto ptolemaico, con el que el rey se sentía tan vinculado a raíz de la boda con Cleopatra Selene; Eudoxo habría llegado a Egipto en la época de Ptolomeo VIII Evérgetes II Fiscón (146-117 a.C.) y se habría relacionado también con sus sucesores, su esposa Cleopatra III y su hijo Ptolomeo IX Soter II Látiro (117-80 a.C.) (Str., II 3.4) ${ }^{66}$ En Egipto se interesó por el curso alto del Nilo en un intento de resolver el problema de sus fuentes, ${ }^{67}$ algo que también le preocupó a Juba (Plin., N.H. V 51); $;{ }^{68}$ el ciciceno habría recorrido también las aguas del Mar Rojo en sus expediciones a la India patrocinadas por Ptolomeo VIII y por su hija y esos territorios fueron asimismo objeto de atención por parte de Juba en su obra Sobre Arabia (Plin., N.H. VI 149-157; 165-

63 Domínguez 2010, 77-93.

64 Por ejemplo, y además del Periplo de Hanón, Diod., V 20; Ps. Ar., Mir. Ausc. 84.1; Plut., Sert. 8; Str., III 2.13 .

65 Plin., N.H. VI 183, 200-202; IX 46. GarCía 2007, 188-194; sobre este autor vid. en último término Mederos 2012, 175-209.

66 Sobre la cronología de los viajes de Eudoxo, vid. Desanges 1978, 152-155; Habicht 2013, 197-206.

67 THIEL 1966, 32.

68 BRAUND 1984a, 175-178. 
177). ${ }^{69}$ La segunda parte de la actividad de Eudoxo tuvo lugar en parte en los territorios que con el tiempo controló el propio Juba. En su primera expedición atlántica toma Gades como punto de partida como no podía ser de otro modo ${ }^{70} \mathrm{y}$, al fracasar, acaba alcanzando los confines del territorio controlado por Boco I hasta cuya corte acude, ${ }^{71}$ aunque no sin antes observar en su navegación una isla rica en agua y en árboles, cuya posición anotó. Sobre cuál pudiera haber sido esa isla las hipótesis son abundantes si bien una parte importante de los investigadores se decantan por alguna de las islas Canarias, ${ }^{72}$ otra por Mogador ${ }^{73}$ y otra por lugares aún más lejanos como Cabo Verde. ${ }^{74}$ Tras escapar de Mauretania ante el temor de que los mauretanos le abandonasen en una isla desierta, regresa a Iberia, seguramente a Gades, quizá previa escala en Carthago Nova como han sugerido algunos autores, ${ }^{75}$ y emprende la última de las expediciones que llegó a conocer Posidonio llevándose consigo dos naves, herramientas agrícolas, semillas y expertos en construcción con el fin de concluir la circumnavegación de África, pero en caso de necesidad, invernar en la isla que había encontrado. No conocemos los resultados de esta última navegación porque, como aseguraba Posidonio, "lo que ocurrió después, es posible que lo sepan en Gadir y en Iberia" (Str., II 3.5). De cualquier modo, el navegante ciciceno habría establecido ya una primera relación con lo que, con el tiempo, se convertiría en el reino de Juba, lo que no dejaría de representar un dato de interés para el rey.

En el relato de Eudoxo se mencionan, pues, una isla rica y fértil, pero también la existencia, en el Atlántico, de imprecisas islas desiertas en las que podría haber sido abandonado. ${ }^{76}$ No cabe duda de que Juba podría haber accedido a las informaciones que se conservasen sobre Eudoxo en lo que en ese momento era su reino si es que las mismas existían; sin embargo, Posidonio daba a entender que habría que acudir a Gades y a Iberia para obtener más informaciones. No veo improbable que Juba, que acabaría instalando una factoría de púrpura en las Islas Purpurarias y que llevaría a cabo una exploración de las Canarias, estuviese interesado en recabar cuantas informaciones pudiese conseguir sobre la expedición del ciciceno, con el que además había compartido intereses y conocimientos (el Nilo, el Mar Rojo) y que, como él, se movía entre el mundo lágida y el mauretano.

69 Para un panorama reciente de las relaciones entre el Mediterráneo y el Océano Índico, vid. SELAND 2014, 367-402.

70 El Houcine 2002, 110-111; Aтоche - Ramírez 2011, 229-256.

71 Sobre la ubicación de la sede real de Boco (Str., II 3.4) y luego de Juba se han avanzado varias hipótesis, siendo Volubilis uno de los centros que se han mencionado a partir, sobre todo, de CARCOPINO 1943, 167-190. Vid. un estado de la cuestión y una inclinación por Gilda en CALlegarin - El Harrif 2000, 27-31. Sobre si Volubilis pudo haber sido una segunda capital de Juba, vid. GHAZI-BEN MAISSA 1994, $243-261$ que critica toda la bibliografía anterior proclive a aceptar lo que, en su opinión, no sería más que una hipótesis infundada. Otros autores, por su parte, parecen apuntar más a Lixus a partir, sobre todo, como en los casos anteriores, de las monedas con la leyenda MQM SMS cuya ceca no ha sido aún localizada con certeza: MANFREDI 1993, 95102. Sobre la importancia de Lixus en época de Juba II, vid. Aranegui 2008, 117-126.

72 Mederos - Escribano 2004, 223-224 con las distintas hipótesis.

73 Desanges 1978, 169.

74 Roller 2010, 98.

75 Mederos - Escribano 2004, 226.

76 Puede tratarse de alguna de las Canarias como han argumentado varios autores; vid. MEDEROS - EsCRIBANO 2004, 225; ROLLER 2010, 98. 
Por consiguiente, en su aproximación a Gades se podrían combinar todos estos elementos; su pretendida ascendencia heraclea le habría sido útil para acercarse, como benefactor o como evérgeta, a la ciudad y a su santuario principal; quizá aportase fondos a la amplia y compleja tarea de renovación de la ciudad de Gades que, bajo el impulso de los Balbos, se había iniciado ya tiempo atrás pero que estaba en pleno auge en su propia época (Str., III 5.3). ${ }^{77}$ En efecto, el teatro de Gades, según los últimos estudios, correspondería al periodo $c a .25-19$ a.C. ${ }^{78}$ mientras que el nuevo Portus Gaditanus sería tal vez de la misma época. ${ }^{79}$ No se conocen con detalle las relaciones que el rey mauretano pudo tener con Balbo el Menor, que sofocó una rebelión de los garamantes entre los años 21-20 a.C. y obtuvo el triunfo por ello en el 19 a.C. (Plin., N.H. V 36-38; Vell. Pat., II 51.3). Frente a otras interpretaciones que sugerían que esa campaña romana se habría hecho ante la incapacidad de Juba de evitar la revuelta, ${ }^{80}$ algunos autores sugieren que la misma se desarrolló fuera del territorio asignado al rey ${ }^{81}$ por lo que no habría habido motivo para que surgiesen rivalidades entre ambos y sí podría haber existido, en cambio, colaboración.

En cualquier caso, el nombramiento de Juba como duunviro de la ciudad de Gades sería la confirmación de que el rey no se habría limitado a una presencia simbólica sino que la misma habría ido acompañada de donaciones económicas. ${ }^{82}$ Ese cargo, que habría implicado que él o, quizá, un praefectus suyo hubiese ejercido la magistratura en su nombre, le habría abierto muchas puertas en la ciudad y allí podría haber llevado a cabo las indagaciones necesarias para conocer el resultado de las averiguaciones de Eudoxo, que muy bien podría haber utilizado para sus propias empresas.

Eudoxo aparece citado en autores posteriores, como Plinio (N.H. II 169) o Mela (III 90) que remiten a Cornelio Nepote. Es difícil saber si algunas referencias en su obra a asuntos de la India (p.ej., Plin., N.H. VII 24) corresponden a este personaje o a su homónimo del s. IV Eudoxo de Cnido. En cambio, a partir del texto de Mela (III 92; $c f$. Plin., N.H. VI 188) parece claro que este personaje debió de dejar informaciones escritas sobre sus viajes aunque quizá privilegiara en las mismas los aspectos más llamativos y chocantes e introdujera incluso elementos fabulosos. Las referencias en Eliano a Eudoxo (N.A. XVII 14) pueden corresponder al ciciceno o, tal vez, a Eudoxo de Rodas. ${ }^{83}$ En el propio Plinio (N.H. II 168) aparece una información que sugiere que Juba, en su obra sobre Arabia, puede haberse hecho eco de alguna noticia tomada bien de Posidonio bien del propio Eudoxo. ${ }^{84}$

Sea como fuere, y consiguiese regresar o no Eudoxo a Gades tras el último viaje que menciona Posidonio, quizá Juba tuviese motivos para pensar que en la ciudad

77 RodRíGUEZ 1992, 289-298; ID. 2011, 307-333.

78 BORREGO 2011, 171-226.

79 CHIC 1983, 105-120; LÓPEZ - PÉREZ 2013.

80 Desanges 1957, 5-43; Coltelloni-Trannoy 1997, 52-53.

81 FALOMIR 2013, 223-227.

82 RodRíGuez 1992, 290 subraya cómo en la mayor parte de los pocos epígrafes de época republicana referidos a censores y quinquenales municipales estos cargos se asocian a la realización de obras públicas.

83 Gómez 1992,151-152 es de la opinión de que las informaciones referidas a Eudoxo presentes en los tres autores se refieren al de Cícico; en el mismo sentido AlbaLADEJo 2007, 246.

84 Mederos - Escribano 2004, 219. 
podía haber informaciones sobre el mismo. A lo largo de la trayectoria de Eudoxo se observa cómo la mayoría de sus viajes cuenta con el patrocinio de reyes (los Lágidas o el fallido intento de convencer a Boco) y solo a veces los realiza con sus propios medios. Tras su regreso a Iberia escapando del rey mauretano pudo volver a equipar otra expedición, lo que sugeriría que quizá poseyese aún fondos, acaso custodiados por alguien de confianza en la ciudad, o que la propia ciudad o algunos de sus ricos comerciantes ( $c f$. Str., III 5.3) podrían haber contribuido a financiar esa última expedición. En cualquiera de los casos, habría huellas de la misma en Gades o, tal vez, en el Heracleo gadirita que habrían sido de interés para el rey Juba, así como el resto de informaciones disponibles en la ciudad sobre las navegaciones atlánticas. ${ }^{85}$ Creyese o no el rey mauretano en la posibilidad de circumnavegar África, que es el motivo que induce a muchos autores a dudar de la veracidad de los viajes y exploraciones del ciciceno, ${ }^{86}$ en las informaciones conocidas y, quizá, en las desconocidas, había datos que podrían ser de interés para Juba en su doble faceta de rey y de geógrafo como la existencia de islas atlánticas hasta entonces desconocidas o mal ubicadas geográficamente y que podrían ser explotadas (como las Purpurarias) o tan solo descritas y exploradas.

Por lo que se refiere a Carthago Nova, mientras que las fuentes literarias callan acerca de cualquier relación entre ella y el rey Juba, son la epigrafía y la numismática las que atestiguan las mismas. Una inscripción honorífica confirma su nombramiento como duunviro quinquenal así como su condición de patrono de la colonia ${ }^{87}$ y en una de las series monetales de la ciudad figura con el cargo de duunviro quinquenal. ${ }^{88} \mathrm{Su}$ hijo Ptolomeo asumiría también con el tiempo el duunvirato quinquenal aunque no, necesariamente, al mismo tiempo que su padre se convertía en patronus como algún autor ha sugerido. ${ }^{89}$

Al igual que en el caso de Gades, tampoco disponemos de datos precisos acerca de las causas que determinaron su nombramiento como magistrado y como patrono. Se ha sugerido que pudo tener que ver con los gastos que ocasionó la construcción de la Vía Augusta y quizá no sea casual tampoco que tanto Gades como Carthago Nova fuesen las dos ciudades de tradición fenicio-púnica más importantes de Hispania y por cuyos puertos habrían salido emigrantes hispanos con destino a las colonias africanas creadas por Augusto. ${ }^{90}$ Otros autores insisten sobre todo en las intensas relaciones entre Hispania y el norte de África, focalizadas en Cesarea y Carthago

85 GAGÉ 1951, 204.

86 Albaladejo 2007, 235-248; por el contrario, una aceptación general del episodio de Eudoxo en DesANGES 1978, 173.

87 CIL II, 3417: Regi Iubae re[gis] / Iubae Filio regi[s] / Iemp[sal]is n(epoti) regis Cau[dae] / pron[epo] ti regis Masiniss[ae] / [p]ronepotis nepoti / IIvir(o) quinq(uennali) patr[o]no / Coloni. ABASCAL - RAMALLO 1997, 191-193, que aceptan una cronología para el epígrafe en el 3-4 d.C. Seguramente se hallaba en el foro: NoGuera - Abascal 2003, 21.

88 Se trata de la emisión XIII de Llorens 1994, 65-67, 145, 225-228; su colega sería Cn. Atellius Ponti... que figura en el anverso. En el reverso, y junto con motivos isíacos aparece el letrero Iuba rex Iubae f(ilius) IIv(ir) Q(uinquennalis). La autora sitúa la emisión entre los años 3-4 d.C. Sobre esta emisión, vid. también BELTRÁN 1980, 135-136, quien sitúa su cronología en el año 9 d.C.

89 Seguí 1996, 1563.

90 Mangas 1988, 734-735, 738. 
Nova a través de las cuales circularían productos de ambos territorios y, en todo caso, dentro de la estrecha relación entre el rey Juba y la familia imperial, cuyos miembros suelen ser los que por lo general aparecen como patroni en esta y en otras ciudades; ${ }^{91}$ otros por fin, en esta línea, apuntan directamente a la exportación hacia Mauretania de productos propios del área de Carthago Nova, tales como esparto, salazones y, sobre todo, plomo. ${ }^{92}$

Los honores otorgados al rey Juba en Carthago Nova debían de relacionarse con eventuales aportaciones económicas a la ciudad en un momento de amplio desarrollo urbanístico como es el periodo de Augusto; ${ }^{93}$ una de las obras principales de ese momento, el teatro, contaba con una vinculación especial a Lucio y Cayo César. ${ }^{94}$ Como vimos con anterioridad, Juba II mantuvo una estrecha relación con este último a raíz de su campaña oriental. Ello no acaba de explicar por completo, sin embargo, por qué Juba se involucra en ese proceso puesto que había otras ciudades que, en la misma época, estaban recibiendo beneficios de la familia imperial y en las que, por el momento, no tenemos atestiguada una intervención del rey mauretano.

Por lo visto hasta ahora debía de haber razones más poderosas que quizá tuvieran que ver con la otra actividad del rey, la histórica y literaria; sin embargo, todo lo que digamos en este sentido no deja de ser hipotético. Las fuentes literarias de que disponemos no nos dan ningún tipo de información acerca de los contingentes que fueron trasladados de África por Asdrúbal en el momento de la fundación de Carthago Nova (Pol., II 13.1; Diod., XXV 10.12); del mismo modo, en el momento de su captura por parte de Escipión, Polibio y Livio distinguen de entre los prisioneros capturados a los ciudadanos y sus mujeres e hijos y a los trabajadores manuales (Pol., X 17.6-9; Liv., XXVI 47.1-3), así como otros habitantes y esclavos (Liv., XXVI 47.4), pero nada nos dicen acerca de sus orígenes o adscripciones étnicas. No sería improbable que, además de la población local que se integró en la fundación cartaginesa junto con colonos de origen púnico, hubiese también gentes de origen númida establecidas en la ciudad, bien desde el momento inicial de la fundación bien más adelante dentro de una política cartaginesa que habría favorecido asentamientos de este tipo; ${ }^{95}$ en cualquier caso, la ciudad habría conservado largo tiempo un evidente carácter púnico poco a poco sustituido por el romano, en especial después de la obtención del estatus colonial, lo que no impidió que en ella siguieran conviviendo los representantes de la antigua aristocracia local con los vinculados a las nuevas clientelas surgidas con Pompeyo y César. ${ }^{96}$

La recreación genealógica que seguramente construye el propio Juba y que ha dejado sus huellas en textos de Plutarco (Sert. 9.8-18) y de Josefo (Ant. Iud. I 240-241)

91 Seguí 1996, 1559-1564; ROLLeR 2003, 157-158.

92 Beltrán 1980, 138-140.

93 Ramallo - Ruiz 2010, 95-110.

94 Ramallo - Ruiz 1998; Ramallo 2003,189-212. Uno de los epígrafes parece datarse, con cierta precisión, entre los años 5 y 1 a.C.

95 Domínguez 1995, 223-239.

96 AbasCal 2002, 21-44. Sobre la pervivencia de antropónimos de origen púnico en Carthago Nova, vid. GoNZÁLEZ et alii 2014, 97-109. 
${ }^{97}$ como veíamos antes, consagraba la ascendencia heraclea del rey pero, al tiempo, se vinculaba con los propios orígenes de su pueblo. Juba, pues, podía justificar la ayuda económica aportada a Carthago Nova, que le valdría los correspondientes honores en la misma, no solo por la coyuntura contemporánea sino tal vez recurriendo a una reconstrucción del pasado en la que figurase, junto con la ascendencia cartaginesa de la ciudad, una eventual presencia númida. Todo ello vendría, además, reforzado, por la relación con el Hércules gaditano. Sin embargo, este dios está poco presente en Carthago Nova. Si, como parece, los nombres que Polibio (X 10.9) asigna a las colinas que caracterizan la topografía de la fundación de Asdrúbal están ocultando divinidades del panteón fenicio púnico, ${ }^{98}$ Melqart no estaría representado entre las mismas. Es cierto, no obstante, que la isla de Escombreras, que cierra la bahía, estaba consagrada a Heracles (Str., III 4.6) y que un epígrafe romano del s. I a.C. (CIL II, 3409) atestigua la veneración en la ciudad del Hércules Gaditano ${ }^{99}$ que, por cierto, constituye el único testimonio de su culto en Hispania fuera del área gaditana y la única referencia epigráfica del mismo. ${ }^{100}$ Del mismo modo, se atestiguan en Carthago Nova los cultos egipcios de Isis y Serapis ${ }^{101}$ a los que era también afecto el rey mauretano (y, sobre todo, su esposa), existiendo un Iseo en su capital Cesarea (Plin., N.H. V 51).

Posiblemente, pues, en la atención que Juba dedicó a Carthago Nova pudo pesar la posible presencia de población de origen númida en la ciudad así como la existencia de un culto al Hércules gaditano que encajaba bien en su propaganda política además, por supuesto, de la existencia de intensas relaciones económicas entre su reino y el gran puerto cartagenero. ${ }^{102}$ Todo ello, dentro de un contexto en el que este tipo de patrocinios se veía alentado por la estrecha relación entre el rey y el princeps que es, sin duda, el trasfondo en el que deben situarse las actuaciones de Juba. Aunque puede que en el futuro nuevos hallazgos amplíen la nómina de ciudades favorecidas por el rey Juba, las dos en las que se atestigua su intervención debían de representar puntos de especial interés desde un punto de vista simbólico pero también económico puesto que Gades y Carthago Nova eran los puntos de comunicación directa entre las dos partes de su reino y la Península Ibérica. Es curioso observar asimismo cómo la otra ciudad en la que se atestiguan las larguezas del rey, Atenas, también había mantenido relaciones con Gades como sugiere Filóstrato y como indicaría la estatua de Temístocles que se encontraba en ella y los sacrificios que realizaban al héroe ateniense Menesteo (Phil., Vit. Apol. Tyan. V 4) que daba también nombre a una localidad próxima a la ciudad (Str., III 1.9). ${ }^{103}$

Como conclusión de lo que aquí hemos ido viendo, podríamos subrayar cómo el rey Juba mantuvo intensos contactos con dos importantes ciudades de la Hispania romana, Gades y Carthago Nova. Sin duda se trataba, como ya han visto algunos

97 LASSÈRE 1979, 232-234.

98 Koch 1982a, 101-113; Noguera 2013, 152-154. Se trataría de Eshmun, Baal Hammon y Chusor.

99 Abascal - Ramallo 1997, 160-161, núm. 35.

100 ORIA 2002, 219-243.

101 Koch 1982b, 347-352; Abascal 2011, 118-119; AbasCAL - Ramallo 1997, 164-167, núms. 37-38.

102 VÁzQuEz 1995, 29-342.

103 BonNet 1987, 259-266. 
autores, ${ }^{104}$ de las dos principales ciudades de origen fenicio-púnico de Hispania pero quizá no fue esta la causa principal de la relación que mantuvo el rey con ellas, al menos de forma directa. Hemos sugerido, para el caso de Gades, la importancia que tuvo para Juba el elaborar una genealogía que lo vinculaba con el Heracles gaditano lo que, al tiempo que contribuía a los gastos en los que estaba incurriendo la ciudad con su importante política de monumentalización le haría un candidato idóneo para que el ordo gadirita le nombrase duunviro. El desempeño de esa magistratura no sabemos si en persona o a través de un praefectus le habría acabado por incluir en los círculos sacerdotales e intelectuales de Gades lo que sin duda le permitió disponer de valiosas informaciones recogidas por sus habitantes a lo largo de los siglos, incluyendo las aportadas por individuos de otras procedencias pero que habían tenido a Gades como centro de operaciones, como era el caso de Eudoxo. En su labor literaria como geógrafo e historiador que, como era frecuente en el mundo antiguo, no estaba demasiado desvinculada de la política, las informaciones de primera mano a las que pudo acceder desde su nueva posición en Gades le resultarían fundamentales no solo para componer su obra Sobre Libia sino, incluso, para llevar a cabo exploraciones y fundaciones en esas islas atlánticas que Eudoxo había vislumbrado y que quizá ya los gadiritas hubieran conocido desde antiguo aun cuando no parece que hayan hecho uso de ese conocimiento. El patronatus o evergetismo, aunque dentro de la más estricta lealtad a la figura de su valedor Augusto, le reportó notables beneficios en el plano intelectual pero también en el político.

Es más difícil ver un vínculo directo con Carthago Nova del rey Juba pero tal vez con su duunvirato y su patrocinio quisiese subrayar su relación con los primeros colonos establecidos por Asdrúbal en una ciudad tan relacionada con su propio reino y sede de cultos tan próximos a él como el del Hércules gaditano y los de Isis y Serapis, que lo vinculaban con la asunción de la herencia lágida a través de su esposa Cleopatra Selene, tal y como había hecho o haría en el gimnasio de los Ptolomeos en Atenas. Aunque en el ejercicio de esas magistraturas pudo haber usado a praefecti tampoco habría que descartar una presencia directa del rey en ambas ciudades; ${ }^{105}$ poco después de haber ejercido su magistratura en Carthago Nova partiría hacia el oriente del Imperio donde llegaría a contraer un segundo matrimonio y donde pasaría un tiempo en compañía de Cayo César, muerto prematuramente en el año 4 d.C., lo que demuestra que no había inconveniente para que el rey abandonase por un tiempo su palacio de Cesarea para dedicarse a sus estudios geográficos siempre necesarios para auxiliar al político y al general. Así pues, el rey Juba, aunque disfrutando de un poder que le había sido otorgado por Augusto, intentó y consiguió actuar según la mejor tradición de muchos reyes helenísticos, aun cuando para ello tuviera que hacer uso de los mecanismos políticos que la nueva era inaugurada por Augusto puso a su disposición. Quizá el juicio de Plinio (N.H. V 16), que consideraba que Juba II fue más digno de recuerdo por su brillantez intelectual que por su reinado (studiorum claritate memorabilior etiam quam regno) sea algo injusto porque, sin duda, los dos

104 PÉReZ 2003, 11-14; Mangas 1988, 731-740.

105 Algunos autores, sin embargo, dudan de la misma o, como mucho, aceptan una presencia esporádica; vid. BeLtrán 1980, 134. 
aspectos fueron complementarios en su actividad como hemos intentado mostrar a propósito de las relaciones de este rey con algunos puntos de la Hispania de Augusto.

\section{BibLIOGRAFÍA}

Abascal Palazón, J. M.

(2002): "La fecha de la promoción colonial de Carthago Nova y sus repercusiones edilicias", Mastia 1, 21-44.

(2011): "El cerro del Molinete y los cultos orientales en Carthago Nova", [en] J. M. Noguera Celdrán - M. J. Madrid Balanza (eds.), Arx Hasdrubalis: la ciudad reencontrada. Arqueología en el Cerro del Molinete, Cartagena, Madrid, 118-119.

Abascal Palazón, J. M.; Ramallo Asensio, S. F. (1997): La ciudad de Carthago Nova: La documentación epigráfica. Vol. 3.1, Murcia.

Albaladejo Vivero, M. (2007): “Algunas consideraciones críticas sobre los viajes de Eudoxo de Cícico", Gerión 25, 235-248.

AleXANDRopoulos, J.

(2000): Les monnaies de l'Afrique Antique. (400 av. J.-C.-40 ap. J.-C.), Toulouse.

(2002-2003): "L'usage du grec en Afrique du Nord d'après les documents monétaires (IIIe s. av. J-C.-Ier s. ap. J.-C.)", Antiquités Africaines 38-39, 289-296.

Álvarez Delgado, J.

(1945): “Las 'Islas Afortunadas' en Plinio", Revista de Historia Canaria 11, 26-61. (1946): "Púrpura Gaetulica", Emerita 14, 100-127.

Álvarez Martí-Aguilar, M. (2014): “¿Mentira fenicia? El oráculo de Melqart en los relatos de fundación de Tiro y Gadir", [en] F. Marco Simón - F. Pina Polo - J. Remesal Rodríguez (eds.) Fraude, mentiras y engaños en el mundo antiguo, Barcelona, 13-33.

Amela VAlVERde, L.

(2012a): "Emisiones reales mauretanas (49-25 a.C.)“, Numisma 256, 29-43.

(2012b): "La situación de Mauretania a finales del Segundo Triunvirato e inicios del principado de Augusto", Gerión 30, 149-167.

AмIтAY, O. (2014): "Vagantibus Graeciae Fabulis: The North African Wanderings of Antaios and Herakles", Mediterranean Historical Review 29, 1-28.

Aranegui Gascó, C. (2008): "La arqueología de Lixus y la monarquía mauritana”, [en] J. M. Candau Morón - F. J. González Ponce - A. L. Chávez Reino (coords.) Libyae lustrare extrema. Realidad y literatura en la visión grecorromana de Africa. Homenaje al Prof. Jehan Desanges, Sevilla, 117-126.

Atoche PeÑa, P.- Ramírez Rodríguez, M. A. (2011): “El archipiélago canario en el horizonte fenicio-púnico y romano del Círculo del Estrecho (circa siglo X a.n.e. al siglo IV d.n.e.)“, [en] J. C. Domínguez Pérez (ed.), Gadir y el Círculo del Estrecho revisados. Propuestas de la arqueología desde un enfoque social, Cádiz, 229-256.

BAllesteros Pastor, L.

(2009): "Troy, between Mithridates and Rome", [en] J. M. Hojte (ed.), Mithridates VI and the Pontic Kingdom. Black Sea Studies, 9, Aarhus, 217-231.

(2013): Pompeyo Trogo, Justino y Mitrídates. Comentario el Epítome de las Historias Filípicas $(37,1,6$ - 38,8,1), Hildesheim. 
Beltrán Martínez, A. (1980): "Iuba II y Ptolomeo de Mauritania, II Viri quinquennales de Carthago Nova", Caesaraugusta 51-52, 133-141.

Bernal Casasola, D. - Raissouni, B. - El Khayari, A. - Díaz, J. J. - Bustamante, M. - Sáez, A. M. - Cantillo, J. J. - Lara, M. - Vargas, J. M. (2014): "De la producción de púrpura getúlica. Arqueomalacología en la cetaria altoimperial de Metrouna", [en] C. Alfaro - M. Tellenbach - J. Ortiz (eds.), Purpureae Vestes IV. Production and Trade of Textiles and Dyes in the Roman Empire and Neighbouring Regions. Actas del IV Symposium Internacional sobre Textiles y Tintes del Mediterrráneo en el mundo antiguo, Valencia, 175-188.

Blanchère, R. De La (1883): De Rege Juba Regis Jubae filio, Paris.

BlázQuez Martínez, J. M.

(1977): "Las Islas Canarias en la Antigüedad", Anuario de Estudios Atlánticos 23, 35-51. (2004): "La explotación de la púrpura en las costas atlánticas de Mauritania Tingitana y Canarias. Nuevas aportaciones", Anuario de Estudios Atlánticos 50, 689-701.

Bonnet, C. (1987): "Une statue de Thémistocle chez les phéniciens de Gadès”, [en] Stemmata. Mélanges de philologie, d'histoire et d'archéologie grecques offerts à J. Labarbe, Lieja-Louvain, 259-266.

Borrego de la PAZ, J. DE D. (2011): “La configuración arquitectónica del Teatro Romano de Cádiz. Nuevas perspectivas”, [en] D. Bernal Casasola - A. Arévalo González (eds.), El Theatrum Balbi de Gades, Cádiz, 171-226.

BRAUND, D.

(1984a): “Anth. Pal. 9.235: Juba II, Cleopatra Selene and the course of the Nile”, CQ 84, $175-178$.

(1984b): Rome and the Friendly King. The Character of the Client Kingship, London.

Callegarin, L. (2008): "La côte maurétanienne et ses relations avec le littoral de la Bétique (fin du IIIe siècle a.C.-Ier siécle P.C.)", Mainake 30, 289-328.

Callegarin, L. - El Harrif, F.Z. (2000): “Ateliers et échanges monétaires dans le 'Circuit du Détroit”", [en] M.P. García-Bellido - L. Callegarin (coords.) Los Cartagineses y la monetización del Mediterráneo Occidental (=Anejos de AEA 22), Madrid, 23-42.

CAMP, J.M. (2001): The Archaeology of Athens, New Haven.

Carcopino, J. (1943): Le Maroc Antique. Paris.

Chic García, G. (1983): “Portus Gaditanus”, Gades 11, 105-120.

Coltelloni-Trannoy, M.

(1990): “Le monnayage des rois Juba II et Ptolémée de Maurétanie, image d'une adhésion réitérée à la politique romaine", Karthago 22, 45-55.

(1992): "Le culte royal sous les règnes de Juba II et de Ptolémée de Maurétanie", [en] Actes du Ve Colloque International Histoire et Archéologie de l'Afrique du Nord. Spectacles, vie portuaire, religions, Paris, 69-81.

(1997): Le royaume de Maurétanie sous Juba II et Ptolémée, Paris.

(2002): "Hercule en Maurétanie: Mythe et Géographie au début du principat", [en] C. Briand-Ponsart - S. Crogiez (eds.), L'Afrique du Nord Antique et Médievale: Mémoire, identité et imaginaire, Rouen, 41-57.

(2005a): "Rome et les rois 'amis et alliés du peuple romain' en Afrique (Ier siècle av. J.C./ Ier siècle ap. J.-C.)", Pallas 68, 117-144.

(2005b): "L'usage du grec dans les royaumes et les provinces romaines d'Afrique", [en] C. Briand-Ponsart (ed.), Identités et culture dans l'Algérie Antique, Rouen, 69-117. 
(2011): “La Maurétanie royale et les débuts de la Maurétanie Césarienne", [en] C. BriandPonsart - Y. Modéran (eds.), Provinces et identités provinciales dans l'Afrique romaine, Caen, 87-109.

DESANGES, J.

(1957): “Le triomphe de Cornélius Balbus, 19 av. J.C.", RAf 101, 5-43.

(1978): Recherches sur l'activité des Méditerranéens aux confis de l'Afrique (VIe siècle avant J.C.-IVe siècle ap. J.C.), Roma.

(1989): "L’hellénisme dans le royaume protégé de Maurétanie (25 avant J.C.-40 aprés J.C.)", BCTHS 20-21, 53-61.

Domínguez Monedero, A. J.

(1995): "Libios, libiofenicios, blastofenicios: elementos púnicos y africanos en la Iberia Bárquida y sus supervivencias", Gerión 13, 223-239.

(2010): "El viaje de Hanón de Cartago y los mecanismos de exploración fenicios", [en] F. Marco - F. Pina - J. Remesal (eds.), Viajeros, peregrinos y aventureros en el Mundo Antiguo, Barcelona, 77-93.

El Houcine, R. (2002): “Les périples de Poseidonius et d'Eudoxe de Cyzique et les contraintes de la navigation en Occident", [en] M. Khanoussi - P. Ruggeri - C. Vismara (eds.), L'Africa Romana 14. Lo spazio marittimo del Mediterraneo occidentle: geografia storica ed economía, Roma, 105-122.

Falomir Pastor, C. (2013): Juba II. Rey de los mauros y los libios. (Tesis Doctoral Universidad de Valencia).

GAGÉ, J. (1951): “Gadès, l'Inde et les navigations Atlantiques dans l'Antiquité", RH 205, 189-216.

García y Bellido, A. (1963): “Hercules Gaditanus”, AEA 36, 70-153.

GARcía García, A. M.

(2007): Juba II, rey de Mauritania: traducción y comentario de sus fragmentos. (Tesis Doctoral Universidad de La Laguna).

(2009): "El informe de Juba II sobre las Fortunatae Insulae (Plinio el Viejo, HN, VI, 202205)", Tabona 17, 141-164.

Ghazi-Ben Maissa, H. (1994): "Volubilis et le problème de regia Jubae", [en] L'Africa Romana. Atti del X Convegno di Studio, Sassari, 243-261.

Gómez Espelosín, F.J. (1992): "Eudoxo de Cícico o el cuento del lobo”, Polis 4, 143-155.

González Fernández, R. - Belmonte Marín, J. A. - Marín Muñoz, J. M. (2014): “C. Cornelius C.F. Sedbal. Nuevo ejemplo de antroponimia fenicio-púnica en Carthago Nova”, CUPAUAM 40, 97-109.

Gozalbes Cravioto, E.

(2003): "El intento de saqueo del Herakleion gaditano y la rebelión de los habitantes de Tingi”, [en] Actas del III Congreso de Historia de Andalucía. Vol. IV. Historia Antigua, Córdoba, 273-282.

(2007a): "Las Islas Atlánticas de la Púrpura (Plinio, NH, VI, 201). Un estado de la cuestión", Anuario de Estudios Atlánticos 53, 273-296.

(2007b): "Nuevas series numismáticas antiguas de la Mauretania occidental", Numisma 251, 39-55.

(2010): “Los orígenes del reino de Mauretania (Marruecos)”, Polis 22, 119-144. 
(2011): “África en el imaginario: las exploraciones geográficas del rey Juba II de Mauretania", Studia Historica. Historia Antigua 29, 153-181.

(2014): "Roma y los africanos. Imperialismo y relaciones de poder con las poblaciones norteafricanas (siglos II-I a.C.)", [en] G. Bravo - R. González Salinero (eds.), Conquistadores y Conquistados. Relaciones de dominio en el mundo romano, Madrid - Salamanca, 271-290.

Grenier, J. C. (2001): “Cléopâtre Séléné reine de Maurétanie, souvenirs d'une princesse”, [en] C. Hamdoune (ed.), 'Ubique amici'. Mélanges offerts à Jean-Marie Lassère, Montpellier, 101-116.

Gsell, S. (1928): Histoire Ancienne de l'Afrique du Nord. VIII. Jules César et l'Afrique. Fin des royaumes indigènes, Paris.

Haвicht, C. (2013): "Eudoxus of Cyzicus and Ptolemaic Exploration of the Sea Route to India", [en] K. Buraselis - M. Stefanou - D. J. Thompson (eds.), The Ptolemies, the Sea and the Nile. Studies in Waterborne Power, Cambridge, 197-206.

HutTner, U. (1997): Die politische Rolle der Heraklesgestalt im griechischen Herrschertum, Stuttgart.

Jacobson, D. M. (2001): "Three Roman Client Kings: Herod of Judaea, Archelaus of Cappadocia and Juba of Mauretania", Palestine Exploration Quarterly 133, 22-38.

Jodin, A. (1967): Les établissements du Roi Juba II aux iles purpuraires (Mogador), Tanger.

$\mathrm{KoCH}, \mathrm{M}$.

(1982a): "Aletes, Mercurius und das phönikisch-punische Pantheon in Neukarthago", $\operatorname{MDAI}(M)$ 23, 101-113.

(1982b): "Isis und Sarapis in Cartago Nova", $M D A I(M)$ 23, 347-352.

KoKkInos, N. (1987): "Re-assembling the inscription of Glaphyra from Athens", ZPE 68, 288-290.

Kontorini, V. N. (1975): "Le roi Hiempsal II de Numidie et Rhodes”, AC 44,89-99.

KRINGS, V.

(1990): "Les libri Punici de Salluste", [en] A. Mastino (ed.), Atti del VII Convegno di studio su L'Africa Romana. Vol. I, Sassari, 109-117.

(1991): "Les lettres grecques à Carthage", [en] C. Baurain - C. Bonnet - V. Krings (eds.), Phoinikeia Grammata. Lire et écrire en Méditerranée, Namur, 649-668.

LANDweHr, C. (2007): "Les portraits de Juba II, roi de Maurétanie, et de Ptolémée, son fils et successeur", $R A 43,65-110$.

LASSÈre, J.M. (1979): “Onomastica Africana I-IV”, Antiquités africaines 13, 227-234.

López Amador, J. J. - Pérez Fernández, E. (2013): El Puerto Gaditano de Balbo. El Puerto de Santa María, Cádiz, El Puerto de Santa María.

López Pardo, F. - Mederos Martín, A. (2008): La factoría fenicia de la isla de Mogador y los pueblos del Atlas, Santa Cruz de Tenerife.

Llorens Forcada, M. M. (1994): La ciudad de Carthago Nova: Las emisiones romanas, Murcia.

Luther, A. (2010): “Zum Orientfeldzug des Gaius Caesar”, Gymnasium 117, 103-127.

MANFREDI, L. I. (1993): “LKS e MGM SMS: nuovi dati del convegno su Lixus 1989”, RSF 21, suppl, 95-102. 
MANFREDI, L. I. (1996): “Un'edicola votiva punica su due serie monetali di Lixus”, $R S F 24$, 47-56.

Mangas Manjarrés, J. (1988): “Iuba II de Mauritania, magistrado y patrono de ciudades hispanas", [en] Actas del Congreso Internacional "El Estrecho de Gibraltar". Vol. I, Madrid, 731-740.

Marín Ceballos, M. C. - Jiménez Flores, A. M. (2011): “Los santuarios fenicio-púnicos como centros de sabiduría: el templo de Melqart en Gadir", [en] M. C. Marín Ceballos (coord.), Cultos y ritos de la Gadir fenicia, Cádiz -Sevilla, 77-109.

Marzoli, D.; El Khayari, A. (2010): "Vorberich Mogador (Marokko) 2008”, MDAI(M) 51, 61-108.

Matthews, V. J. (1972): “The Libri Punici of King Hiempsal”, AJPh 93, 330-335.

Mattingly, D. J. (2011): Imperialism, power and identity. Experiencing the Roman Empire, Princeton.

MaZARD, J. (1955): Corpus Nummorum Numidiae Mauretaniaeque, Paris.

Mederos Martín, A.

(2012): "Las columnas de Atlas. El Periplo africano de Statius Sebosus de Gades a las Islas Afortunadas", [en] F. Prados Martínez - I. García Jiménez - G. Bernard (eds.), Confines. El extremo del mundo durante la Antigüedad, Alicante, 175-209.

(2013): “Los periplos atlánticos norteafricanos de Polibio y Juba II transmitidos por Plinio (N.H., V, 9-10)", Gerión 31, 239-268.

Mederos Martín, A. - Escribano Cobo, G.

(2002): "Las Islas Afortunadas de Juba II. Púnico-gaditanos y romano-mauretanos en Canarias", Gerión 20/1, 315-358.

(2004): "Los periplos de Eudoxo de Cízico en la Mauretania Atlántica", Gerión 22, 215 233.

(2006): "Mare purpureum. Producción y comercio de la púrpura en el litoral atlántico norteafricano", RSF 34, 71-96.

Mierse, W. E.

(1993): "Temple Images on the Coinage of Southern Iberia", Revue Belge de Numismatique 139, 37-57.

(2004): "The Architecture of the Lost Temple of Hercules Gaditanus and Its Levantine Associations", AJA 108, 545-576.

Miller, S. G. (1995): “Architecture as Evidence for the Identity of the Early Polis", [en] Sources for the Ancient Greek City-State. Acts of the Copenhagen Polis Centre, 2, Copenhague, 200-244.

MÜLLER, L.

(1862), Numismatique de l'ancienne Afrique. III. Les monnaies de la Numidie, Copenhague.

(1874): Numismatique de l'ancienne Afrique. Supplément, Copenhague.

Noguera Celdrán, J. M. (2013): “Qart Hadast, capital bárquida de Iberia”, [en] M. Bendala Galán (ed.), Fragor Hannibalis. Aníbal en Hispania, Madrid, 135-173.

Noguera Celdrán, J. M. - Abascal Palazón, J.M. (2003): "Fragmentos de epígrafes e inscripción con litterae aureae del foro y del Augusteum de Carthago Nova", Mastia 2, 11-63. 
Oggiano, I. (2008): "Lo spazio fenicio rappresentato", [en] X. Dupré - S. Ribichini - S. Verger (eds.), Saturnia Tellus. Definizioni dello spazio consagrato in ambiente etrusco, italico e céltico, Roma, 283-300.

Oria Segura, M. (2002): "Religión, culto y arqueología: Hércules en la Península Ibérica", [en] E. Ferrer Albelda (ed.), Ex Oriente Lux. Las religiones antiguas en la Península Ibérica, Sevilla, 219-243.

PARIGI, C. (2013): “The Romanization of Athens: Greek Identity and Connectivity between Athens and Rome in the 1st Century BC.", [en] L. Bombardieri - A. D'Agostino - G. Guarducci - V. Orsi - S. Valentini (eds.), SOMA 2012. Identity and Connectivity. Vol. I. BAR Int. Ser. 2581, Oxford, 447-455.

Peretti, A. (1979): Il periplo di Scilace. Studio sul primo portolano del Mediterraneo, Pisa.

PÉreZ Vilatela, L. (2003): "La geografía hispánica de Juba II: Iberia y las Canarias (y apuntes sobre las aguas oceánicas)", Anexos de El Miliario Extravagante, 5, Cortes de la Frontera.

Ramallo Asensio, S. F. (2003): "Los príncipes de la familia Julio-Claudia y los inicios del culto imperial en Carthago Nova", Mastia 2, 189-212.

Ramallo Asensio, S. F. - Ruiz Valderas, E.

(1998): El teatro romano de Carthago Nova, Murcia.

(2010): “Carthago de Hispania, emporio comercial del Mediterráneo occidental", [en] R. González Villaescusa - J. Ruiz de Arbulo (eds.), Simulacrae Romae II. Rome, les capitales de province (capita provinciarum) et la création d'un espace commun européen: une approche archéologique, Reims, 95-110.

Rodríguez NeILA, J. F.

(1992): Confidentes de César: Los Balbos de Cádiz, Madrid.

(2011): "Los Cornelios Balbos. Política y mecenazgo entre Gades y Roma”, [en] D. Bernal Casasola - A. Arévalo González (eds.), El Theatrum Balbi de Gades, Cádiz, 307-333.

ROLLER, D. W.

(2003), The World of Juba II and Kleopatra Selene. Royal scholarship on Rome's African frontier, London.

(2010): "The strange tale of Eudoxos of Kyzikos: adventurer and explorer of the Hellenistic world", [en] F. Marco - F. Pina - J. Remesal (eds.), Viajeros, peregrinos y aventureros en el Mundo Antiguo, Barcelona, 95-99.

SAlzManN, D. (1974): "Die Münzen der Mauretanischen Könige Juba II. und Ptolemaios", $\operatorname{MDAI}(M)$ 15, 174-183.

Santana Santana, A. - Arcos Pereira, T. - Atoche Peña, P. - Martín, J. (2002): El conocimiento geográfico de la costa noroccidental de Africa en Plinio: La posición de las Canarias, Hildesheim.

Schmalz, G. C. R. (2009): Augustan and Julio-Claudian Athens. A New Epigraphy and Prosopography, Leiden.

Schmitt, P. (1968): “Connaissance des Iles Canaries dans l'Antiquité”, Latomus 27, 362-391.

Seguí Marco, J. J. (1996): “Un aspecto particular en las relaciones hispano-africanas durante el Alto Imperio: los patrocinios públicos”, [en] M. Khanoussi - P. Ruggeri - C. Vismara (eds.), L'Africa Romana. Atti del XI Convegno di Studio. Vol. III, Sassari, 1547-1564. 
SELAND, E. H. (2014): “Archaeology of Trade in the Western Indian Ocean, 300 BC-AD 700”, Journal of Archaeological Research 22, 367-402.

Sirago, V. A. (1996): “Il contributo di Giuba II alla conoscenza dell'Africa”, [en] L'Africa Romana. Atti del XI Convegno di Studio, Sassari, 303-317.

SmadJA, E. (1994): “Juba II Hercule sur le monnayage maurétanien”, [en] M.M. Mactoux - E. Geny (eds.), Mélanges P. Lévêque. 8.- Religion, anthropologie et société, Paris, 371-388.

Tarradell, M. (1960): Marruecos Púnico, Tetuán.

Thiel, J. H. (1966): Eudoxus of Cyzicus. A chapter in the history of the sea-route to India and the route round the Cape in ancient times, Groningen.

TyldeSLeY, J. (2008): Cleopatra. Last Queen of Egypt, London.

VÁzQuez Hoys, A. M. (1995): "El comercio entre Hispania y Mauritania y el Templo de Hércules Melkart en Gades en la época de Iuba II y Ptolomeo", [en] E. Ripoll Perelló - M. F. Ladero Quesada (eds.), Actas del II Congreso Internacional El Estrecho de Gibraltar. II.- Arqueología Clásica e Historia Antigua, Madrid, 329-342. 